\title{
Effects of sediment properties and organic matter on biomobilization of arsenic from aquifer sediments in microcosms
}

\author{
Z. Xie, M. Chen, J. Wang, X. Wei, F. Li, J. Wang \& B. Gao \\ School of Environmental Studies, China University of Geosciences, Wuhan, Hubei, P.R. China
}

\begin{abstract}
In this study, the reducing capacity of the strain Bacillus cereus in the two sediments from Datong Basin and Jianghan Plain was investigated by examining the concentrations of As and Fe and the changes of $\mathrm{pH}$ and Eh. Results showed that glucose contributed to the mobilization of As and Fe, and As in the sediment from Jianghan Plain was released more easily. It was found that Bacillus cereus changed the $\mathrm{pH}$ and Eh in the surroundings, and promoted the reductive dissolution of $\mathrm{As}(\mathrm{V})$ and $\mathrm{Fe}(\mathrm{III})$ in the sediments to enhance As in groundwater.
\end{abstract}

\section{INTRODUCTION}

Arsenic (As) is an important element for human carcinogen. More and more people are suffering arsenism for long-term drinking arsenic-contaminated groundwater. Mobilization and enrichment of arsenic in groundwater were affected by several environmental factors.

The objectives of this study were to evaluate the influences of sediment properties and organic matter on bacterial migration of arsenic.

\section{MATERIALS AND METHODS}

\subsection{Bacterial culture}

The strain Bacillus cereus (B. cereus) was isolated from the aquifer sediment. The bacterial strain was cultured in modified minimal salt medium (MSM) in an incubator in dark at $25^{\circ} \mathrm{C}$ for $4 \mathrm{~d}$. Salts supplied per liter of MSM were: $0.14 \mathrm{~g} \mathrm{KH}_{2} \mathrm{PO}_{4}, 0.50 \mathrm{~g} \mathrm{KCl}$, $1.00 \mathrm{~g} \mathrm{NaCl}, 0.13 \mathrm{~g} \mathrm{CaCl}_{2}$ and $0.62 \mathrm{~g} \mathrm{MgCl}_{2} \cdot 6 \mathrm{H}_{2} \mathrm{O}$. The bacterial cells were harvested by centrifugation at $4000 \mathrm{rpm}$ for $20 \mathrm{~min}$ at $4^{\circ} \mathrm{C}$. The cell pellets were resuspended and cultured in the fresh MSM for the next experiments.

\subsection{Sediment characterization}

Total organic $\mathrm{C}$ (TOC), As, Fe, $\mathrm{pH}$ and mineral size distribution of sediment particles were determined as the methods described in Simmler et al. (2016).

\subsection{Microcosm experiments}

Two sediment samples were collected from high arsenic aquifers at Datong Basin and in Jianghan Plain. The two samples were named as SDB and SJP, respectively. The microcosms were prepared in $500 \mathrm{~mL}$ Erlenmeyer flasks with rubber stoppers. In $\mathrm{N}_{2}$ filled glove box, $10 \mathrm{~mL}$ of the bacterium in exponential growth phase were incubated in the Erlenmeyer flask with $0.4 \mathrm{~g}$ glucose or $0.5 \mathrm{~g}$ fulvic acid, $20 \mathrm{~g}$ sieved sediment and $200 \mathrm{~mL}$ deionized water. Sediment, Erlenmeyer flask and deionized water were autoclaved prior to use. All the Erlenmeyer flasks were incubated in nitrogen atmosphere, in dark at $25^{\circ} \mathrm{C}$. The control groups without organic matter or bacterium were run under the same conditions.

\subsection{Chemical analyses of the aqueous phase}

Before collecting the samples, $\mathrm{pH}$ and Eh were measured directly in the water-sediment system in the $\mathrm{N}_{2}$-filled glove box. Dissolved As(III), As(V), Fe(II) and $\mathrm{Fe}(\mathrm{III})$ in the solutions from the microcosms were determined. At regular time intervals, $5 \mathrm{~mL}$ of sample were removed from each reaction vessel and centrifuged. As(III) and As(V) were separated from the supernatant by a strong anion exchange column and measured by hydride generation-atomic fluorescence spectrometry. $\mathrm{Fe}(\mathrm{II})$ and $\mathrm{Fe}(\mathrm{III})$ were determined according to the method of Han et al. (2011).

\section{RESULTS AND DISCUSSION}

\subsection{Sediment characterization}

The content of sand in the two samples was high as shown in Table 1. Nevertheless, sand in SJH had higher percentage. The $\mathrm{pH}$ values of SDB and SJP were in slightly alkaline. The contents of TOC in sediments had obvious difference. In addition, the contents of As and Fe in SDB exceeded in SJH. The results indicated that the two sediment samples had different characterization.

\subsection{Speciation and mobilization of As and $\mathrm{Fe}$}

The concentrations of dissolved As(V), As(III), Fe(III) and $\mathrm{Fe}(\mathrm{II})$ in aqueous phase in the microcosm were presented in Figure 1. From the figure, we can see that all the concentrations increased over time under the condition of bacterial activities. The concentrations of 


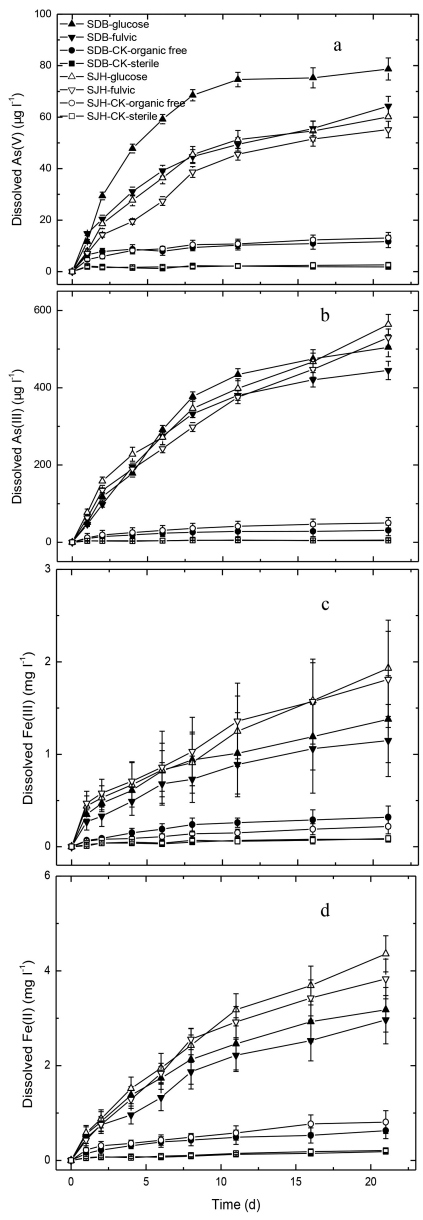

Figure 1. Dissolved As(V), As(III), Fe(III) and Fe(II) in aqueous phase in the microcosm. a) $\mathrm{As}(\mathrm{V})$; b) $\mathrm{As}(\mathrm{III})$; c) $\mathrm{Fe}(\mathrm{III})$; d) $\mathrm{Fe}(\mathrm{II})$.

Table 1. Physicochemical characteristics of sediment samples.

\begin{tabular}{lcc}
\hline & SDB & SJH \\
\hline $\mathrm{pH}$ & 7.9 & 7.6 \\
$\mathrm{TOC}(\%)$ & 0.19 & 0.56 \\
${\mathrm{As}\left(\mathrm{mg} \mathrm{kg}^{-1}\right)}_{\mathrm{Fe}_{2} \mathrm{O}_{3}(\%)}^{13.3}$ & 9.8 \\
$\mathrm{Sand}(50-2000 \mu \mathrm{m})(\%)$ & 2.89 & 2.23 \\
$\mathrm{Silt}(2-50 \mu \mathrm{m})(\%)$ & 61.7 & 76.8 \\
Clay $(<2 \mu \mathrm{m})(\%)$ & 27.7 & 18.3 \\
\end{tabular}

$\mathrm{As}(\mathrm{III})$ and $\mathrm{Fe}(\mathrm{II})$ exceed those of $\mathrm{As}(\mathrm{V})$ and $\mathrm{Fe}(\mathrm{III})$ at the same sampling time. Additionally, the concentrations except $\mathrm{As}(\mathrm{V})$ in $\mathrm{SJH}$ microcosm were higher than in SDB microcosm. Glucose contributes to the mobilization of As and Fe. The results suggested that $B$. cereus promoted the reductive dissolution of As( $\mathrm{V})$ and $\mathrm{Fe}(\mathrm{III})$ in the sediments.

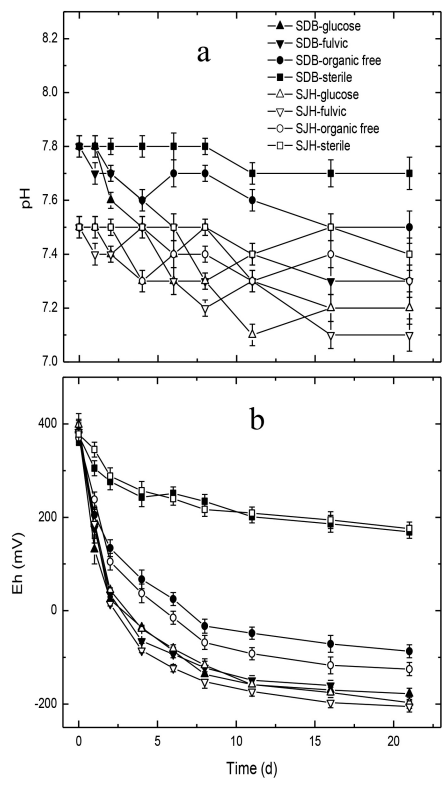

Figure 2. Change of $\mathrm{pH}$ and Eh. a) $\mathrm{pH}$; b) Eh.

\subsection{Change of Eh and $\mathrm{pH}$}

It was shown that $B$. cereus affected the $\mathrm{pH}$ and $\mathrm{Eh}$ of the microcosms microcosms (Fig. 2). The change of $\mathrm{pH}$ and Eh contributed to mobilization of As and Fe.

\section{CONCLUSIONS}

From this study, it was found that the strain Bacillus cereus changed the environment factors and promoted the reductive dissolution of $\mathrm{As}(\mathrm{V})$ and $\mathrm{Fe}(\mathrm{III})$ in the sediments. Then, As and Fe were released into groundwater from sediments.

\section{ACKNOWLEDGEMENTS}

This research work was financially supported by National Natural Science Foundation of China (Grant Nos. 41572230 and 41172219), and by the Grant for Innovative Research Groups of the National Natural Science Foundation of China (41521001).

\section{REFERENCES}

Han, X., Li, Y.L. \& Gu, J.D. 2011. Oxidation of As(III) by $\mathrm{MnO}_{2}$ in the absence and presence of $\mathrm{Fe}(\mathrm{II})$ under acidic conditions. Geochim. Cosmochim. Acta. 75: 368-379.

Simmler, M., Suess, E., Christl, I., Kotsev, T. \& Kretzschmar, R. 2016. Soil-to-plant transfer of arsenic and phosphorus along a contamination gradient in the mining-impacted Ogosta River floodplain. Sci. Total Environ. 572: 742-754. 